\title{
Fig Wax Scale, Ceroplastes rusci (L.) (Insecta: Hemiptera: Coccoidea: Coccidae) ${ }^{1}$
}

Avas B. Hamon and Gregor J. Mason²

\section{Introduction}

The fig wax scale, Ceroplastes rusci (L.), was first discovered in Florida at several nursery and stock dealers in 1994 and 1995. It has been a pest of Ixora spp. and infrequently found on other host plants. Prior to these discoveries, the California Department of Food and Agriculture had intercepted specimens from Florida.

\section{Distribution}

Talhouk (1975) reported the presence of this scale in the Mediterranean region (Algeria, Cyprus, Egypt, Greece, Israel, Italy, Lebanon, Morocco, Spain, Tunisia and Turkey) and Argentina. The fig wax scale has more recently been found in the Austro Oriental region (Irian Jaya), Ethiopian region (Angola, Cape Verde Islands, Zimbabwe), Malagasian region (Aldabra Island), Neotropical region (Antigua, Brazil, Guyana, Puerto Rico, Virgin Islands), Palaearctic region (Afghanistan, Azores Islands, Canary Islands, Corsica, Crete, France, Iraq, Madeira, Portugal, Saudi Arabia) (Ben-Dov 1993). Positive identifications in Florida have been made in
Broward, Dade, Manatee, Palm Beach, Pasco and Pinellas counties.

\section{Description}

This scale is deeply encased in pinkish-gray wax, which is divided into three wax plates on each side with additional plates at the anterior and posterior ends. The single large dorsal plate has a central nucleus. Dorsal and lateral plates are separated from each other by dark red lines which are the color of the scale's body beneath the wax. The anterolateral and mediolateral plates have some white wax which indicates the stigmatic wax bands.

\section{Biology}

The biology of the fig wax scale has not been studied in Florida but has been described on fig trees in Israel (Bodkin 1927). In general, adult females overwinter on twigs and produce eggs very early in the spring. The eggs hatch to crawlers which move to feed on leaves. After about one month, the crawlers molt to 2nd instar nymphs and migrate to the leaf petioles or to new shoots. Maturity is attained in the summer, and a new generation of crawlers is

1. This document is EENY-187 (originally published as DPI Entomology Circular 380), one of a series of Featured Creatures from the Entomology and Nematology Department, Florida Cooperative Extension Service, Institute of Food and Agricultural Sciences, University of Florida. Published: January 2001. This document is also available on Featured Creatures Website at http://creatures.ifas.ufl.edu. Please visit the EDIS Website at http://edis.ifas.ufl.edu.

2. Avas B. Hamon and Gregor J. Mason, Florida Department of Agriculture and Consumer Services, Division of Plant Industry, Gainesville, Florida.

The Institute of Food and Agricultural Sciences (IFAS) is an Equal Employment Opportunity - Affirmative Action Employer authorized to provide research, educational information and other services only to individuals and institutions that function without regard to race, creed, color, religion, age, disability, sex, sexual orientation, marital status, national origin, political opinions or affiliations. For information on obtaining other extension publications, contact your county Cooperative Extension Service office. Florida Cooperative Extension Service / Institute of Food and Agricultural Sciences / University of Florida / Larry R. Arrington, Interim Dean 


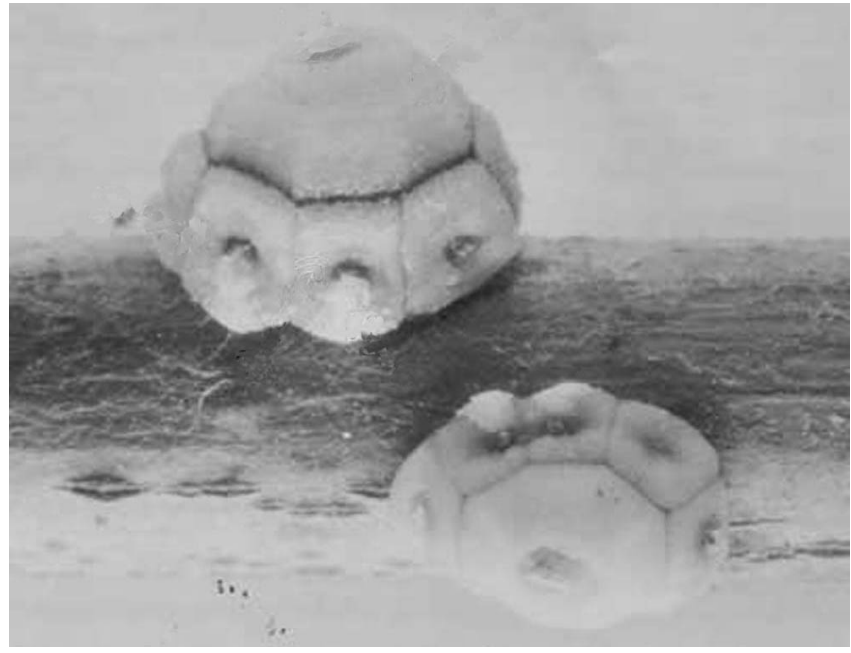

Figure 1. Adult female fig wax scale, Ceroplastes rusci (L.). Credits: Jeffrey Lotz, Division of Plant Industry

produced. These nymphs mature late in the fall, overwinter on the twigs, and repeat the cycle (Bodkin 1927). Swailem and Awadallah (1973) reported scales to be equally present on both upper and lower leaf surfaces on fig trees in Egypt.

\section{Host Plants}

The fig wax scale has been reported on a broad range of host plants including the following families: Anacardiaceae (Mangifera indica, Schinus terebinthifolius), Annonaceae (Annona cherimoya, A. muricata, A. squamosa), Apocynaceae (Nerium oleander, Thevetia peruviana), Aquifoliaceae (Ilex aquifolium), Araliaceae (Hedera helix), Balsaminaceae (Impatiens sultani), Compositae (Artemisia), Convolvulaceae (Convolvulus, Ipomoea batatus), Euphorbiaceae (Euphorbia longan), Lauraceae (Laurus nobilis, Persia americana), Moraceae (Ficus sp., Morus alba, M. nigra), Musaceae (Musa cavendishi, M. sapientum), Myrtaceae (Myrtus communis, Psidium guajava), Palmae (Chamaerops humilis), Pittosporaceae (Pittosporum tobira), Platanaceae (Platanus orientalis), Proteaceae (Grevillea robusta), Rosaceae (Crataegus vulgaris, Prunus dulcis, Pyrus communis), Rutaceae (Citrus aurantium, C. limon, $C$. paradisi), Sapindaceae (Litchi chinensis, Nephelium lappaceum, Sapindus saponaria), Sebestenaceae (Cordia myxa), Strellitziaceae (Strelitzia reginae), and Vitidaceae (Vitis vinifera) (Ben-Dov 1993). It has also been found feeding on Citrus sinensis and $C$. reticulata in Greece (Argyriou and Mourikis 1981).
In Florida, specimens of this scale have been identified on Annona squamosa (sugar apple), Mimusops roxburghiana (mimusops), Phoenix roebelenii (pygmy date palm), and Ixora spp.

\section{Economic Importance}

The fig wax scale has been reported as a pest of citrus in Italy (Talhouk 1975). Infrequent major local infestations in the citrus-growing areas of Italy have been controlled with refined petroleum oils (Barbagallo 1981). Similar outbreaks occurring in the Aegean Islands, Greece, have been controlled by the application of oils in the summer. The presence of parasites [Coccophagus lycimnia Walker (Aphelinidae), Scutellista cyanea Motschulsky (Pteromalidae)] aid in keeping populations of the fig wax scale under control (Argyriou and Mourikis 1981).

\section{Management}

See the following for management information:

Florida Citrus Pest Management Guide for Scales

Insect Management Guide for Landscape Pests

\section{Selected References}

Argyriou LC, Mourikis PA. 1981. Current status of citrus pests in Greece. Proceedings of the International Society of Citriculture 2: 623-627.

Barbagallo S. 1981. Integrated control of citrus pests in Italy. Proceedings of the International Society of Citriculture 2: 620-623.

Ben-Dov Y. 1993. A systematic catalogue of the soft scale insects of the world. Sandhill Crane Press, Inc., Gainesville, FL. Flora and Fauna Handbook No. 9. $536 \mathrm{p}$.

Bodkin GE. 1927. The fig wax scale (Ceroplastes rusci L.) in Palestine. Bulletin of Entomological Research 17: 259-263.

Swailem SM, Awadallah KT. 1973. On the seasonal abundance of the insect and mite fauna on the leaves of sycamore fig trees. Bulletin de la Société Entomologique d'Egypte 57: 1-8. 
Fig Wax Scale, Ceroplastes rusci (L.) (Insecta: Hemiptera: Coccoidea: Coccidae)

Talhouk AMS. 1975. Citrus pests throughout the

world. Ciba-Geigy Agrochemicals, Basel,

Switzerland. Technical Monograph No. 4. 21 p. 